Agro-Science Journal of Tropical Agriculture, Food, Environment and Extension Volume 17 Number 3 (September 2018) pp. 34-39

ISSN 1119-7455

\title{
FACTORS INFLUENCING RURAL-URBAN MIGRATION OF YOUTHS IN OSUN STATE, NIGERIA
}

\author{
Alarima, C.I. \\ Department of Agricultural Extension and Rural Development, \\ Federal University of Agriculture, Abeokuta, Nigeria \\ Author's email: corneliusalarima@yahoo.com
}

\begin{abstract}
This study examined the factors influencing rural-urban migration of youths in Osun State, Nigeria. A multistaged sampling technique was employed in the selection of 240 of the respondents (youth) from three local government areas of the state. Data for this study were sourced primarily through the use of well-structured questionnaire. Both descriptive and inferential analyses were employed in the analyses of the data. The result of this study showed that mean age of the respondents was 22.60 years. The study further revealed that majority (68.8\%) of the respondents were male, single, had family size of between 5 - 8 and had secondary education. The results revealed that the poor electricity supply in the rural areas, bad condition of roads, absence of pipe-borne water were push factors driving the youth away from their communities into urban areas. Results further revealed that better employment opportunities, superior wages in the urban areas, improved living condition are pull factors that attract rural youths to the urban centres. Majority (68.8\%) of the respondents were not willing to stay in the rural areas with or without improvement in the condition of living in their communities. The results of this study revealed that age $(r-0.51 ; p<0.01)$, sex $\left(\chi^{2}-34.57 ; p<\right.$ $0.05)$ and educational level $\left(\chi^{2}-45.57 ; p<0.01\right)$ of the respondents were significantly related to their decision to migrate from rural to urban areas. The study recommends that government should provide basic social amenities in the rural areas as they are found in the urban so as to encourage the youth to stay.
\end{abstract}

Key words: Rural, urban, migration, youth

\section{INTRODUCTION}

Apart from population dynamics of birth and death or reproduction, migration exerts a critical influence on population size, composition and distribution (Knox and Marston 2004). Over the years, migration dynamics has changed from the search for space, especially in the middle age to that of congestion in large cities in the modern age (Nwajiuba 2005). Migration to Adewale (2005) is considered as the movement of people from one geographical region to another, which may be on temporary or permanent basis. Migration is a selective process affecting individuals or families with certain economic, social, educational and demographic characteristics (Adewale, 2005). Migration was initially viewed favourably as a natural process of transferring surplus labour from the rural sector to the urban industrial sector and migrants would find well paying jobs in urban areas and send remittances to their families, thereby improving the welfare of rural folks left behind (Gilbert \& Gugler, 1992). Unfortunately, this has not been the case in recent years due to the phenomenon of urban surplus labour, leading to urban unemployment problems (Todaro, 1976) and urban cash economy where a decline in wages makes them vulnerable to a multiplicity of problems even worse than in the rural areas (Tindigarukayo, 2014). People tend to be pulled to the areas of prosperity and pushed from areas of decline placing more emphasis on the benefits to be derived by moving and with less attention to the problems and challenges that they may face as a result of the movement (Braunvan, 2004). Migration affects people with economic, social, educational and demographic peculiarities (Amrevurayire and Ojeh, 2016). Migration follows a variety of patterns on space dimension which include urban-urban; urban-rural; rural-rural and rural-urban (Eze, 2016). Rural-urban migration results from movement from rural to urban in the search for opportunities due to rural-urban inequality in wealth and better quality of life found in urban centres. Three categories of factors are perceived as responsible for rural-urban migration which include those related to the need for education and acquisition of skills in various vocations; those related to the absence of desirable job opportunities in rural areas which are absence of employment, absence of industries and companies and boredom in agriculture; and finally those factors relating to social, such as inadequate 
amenities (Aworemi et al, 2011). Rural-urban migration can also be associated with economic issues, improved standard of living, improper health services and other amenities and infrastructure in urban centers. Rural-urban migration poses some problems in the rural as well as in the urban. The movement results to human and environmental poverty, the declining quality of life and the underutilized and untapped wealth of human resources as well as rapid deterioration of the rural economy leading to chronic poverty and food insecurity (Mini, 2000).

Further, inadequate housing and associated facilities (such as water, electricity, waste disposal) in the urban areas resulting in millions living in substandard environments called slums and grossly inadequate social amenities, such as, a shortage of schools, poor health facilities and lack of opportunities for recreation among others. Migration to urban areas is placing pressure on limited appropriate housing, resulting in increases in the numbers of urban residents now found to reside in informal housing (Amrevurayire \& Ojeh, 2016). Rural communities share this burden through loss of manpower necessary for agricultural activities and production. It also results into reduction in agricultural productivity which in turn leads to food insecurity and soaring price of food. Consequently, agriculture which prior to discovery of oil was the mainstay of Nigeria's economy with activities concentrated in the rural areas was far relegated to the background leading to the country's mono-economy status (Amrevurayire and Ojeh, 2016).

Having highlighted various effects and causes of rural - urban migration especially on agricultural production, this study aim to assist the development planners, policy makers and government on how to make policy that will take care of the push factors in the rural areas and other pull factors in urban areas thus make life more meaningful for our youth in the rural communities thereby reducing the rate of rural-urban migration. This study therefore aims at examining the factors influencing youth rural-urban migration in Osun State. The specific objectives are to determine the socio-economic characteristics of youths in Osun state examine the willingness of the youth towards staying in the rural communities; examine the effects of youth rural-urban migration in Osun State and identify the determinants of the youth rural-urban migration in Osun State.

\section{MATERIALS AND METHODS \\ Study Area}

Osun State covers an area of approximately 9,251 square kilometer. The state is an inland state in south-western Nigeria. Its capital is Osogbo. It is bounded in the north by Kwara State, in the east 16-25 years, while $25.2 \%$ were between the age partly by Ekiti State and partly by Ondo State, in the south by Ogun State and in the west by Oyo State. The state has a population of $34,137,627$ based on the 2006 provisional census figures. The major ethnic group in Osun state is Yoruba with sub-ethnic groups such as Ife, Ijesha, Oyo, Ibolo and Igbomina and there are also people from other parts of Nigeria. Yoruba and English are widely spoken in the state. The people of the state are mostly traders, artisans, and farmers. The farmers produce food crops such as yam, maize, cassava, beans and cocoyam. The cash crops include tobacco, and palm produce. The artisans make hand-woven textiles, tie and dye clothes, leather work, calabash carving and mat-weaving. The state is also enriched with mineral resources such as gold, clay, limestones and granite (Wikipedia, 2018). This study was carried in three local government areas namely Aiyedaade, Oriade and Odo Otin.

\section{Sampling Technique and Sample Size}

A multi-staged sampling technique was employed in the selection of the respondents (youth). The first stage involved the random selection of three Local Government Areas among 30 Local Governments in Osun State. These are Aiyedaade Local Government, Oriade Local Government, and Odo Otin Local Government. The selection covers the three political senatorial districts. The second stage involved the random selection of two wards/districts from each local government area. The third stage involved the random selection of two villages in each of the selected wards/districts. While the final stage however involved a purposive selection of 20 youths from each selected village. Thus, giving a total of 240 respondents for the study.

\section{Data Collection Procedure and Data Analysis}

The data collected were socio - economic characteristics of the respondents, which include variables like age in years, sex, household size, education level and marital status etc. Data were also obtained the respondents' willingness to stay in rural areas. Furthermore, respondents' opinion on the perceived effects of the rural-urban migration were also sourced for. Data were also obtained on push (making them move away from the rural community) and pull (making them stay in the urban centre) factors responsible for rural-urban migration. Both descriptive and inferential analyses were employed in the analyses of the data.

\section{RESULTS AND DISCUSSION Socio-economic Characteristics of the Respondents}

The result of this study (Table 1) showed that mean age of the respondents was 22.60 years. Majority of the respondents were between the age group of group of $26-30$ years. This shows that majority of 
the respondents were within their youthful stage of development, a stage when a child begins to operate independently from the parents and it is assumed that at this age, a ward could be allowed by the parent to travel out of their communities. The study also agreed with the finding of Mutandwa et al. (2011) who found out that youths who are likely to migrate are predominantly aged between 17 to 22 years. The study further revealed that majorities $(68.8 \%)$ of the respondents were male while $31.3 \%$ were female. This implies that there were more male than the female in the study area. Majority $(66.3 \%)$ of the respondents have household size of between 5 and 8 . This implies that majority of the households in the rural areas are larger in size than their urban counterpart which usually have between 1 and 4 members. This finding is in agreement with Ehirim et al. (2012) and Ango et al., (2014) who reported that the household size of rural people is always much when compared to its counterpart living in the city because of their dependence on the family as a source of farm labour. Table shows that $76.3 \%$ of the respondents had secondary education with few $(11.3 \%)$ had tertiary education. The result of the study also implies that none of the respondents was illiterate, as they had attained one form of education or the other. Also, it was observed that
$48.8 \%$ of the respondents were Christian while 47.5\% were Muslim. This implies that Christianity and Islam have dominated. Also, the Table shows that majority $(70 \%)$ of the respondents were single, while $30 \%$ were married. This finding indicated that majority of the respondents were single which could make it easy for them to travel out of the village due to less responsibility of caring for wife and children. This finding is in conformity with the finding of Abdur-Rokib and Abdul-Goni (2011), Ehirim et al. (2012), Pradhan (2013) and Ango et al. (2014) who reported that the single people among the members of the society migrated more than the married ones, which could be attributed to the fact that those married may find it difficult to move without their household members.

\section{The Push Factors for Leaving the Rural Areas} The results in Table 2 reveals that the poor electricity supply in the rural areas $(92.5 \%)$, bad condition of roads in rural area $(80.0 \%)$, absence of pipe-borne water $(75.0 \%)$ were push factors driving them away from their communities into urban Areas. Also, poor condition of rural schools, lack of employment in rural area, poor health care services, under development of rural areas were other push factors making the youths to move out of rural communities.

Table 1: Selected socio-economic characteristics of respondents $(n=240)$

\begin{tabular}{lccc}
\hline Variable & F(\%) & Mean & S.D \\
\hline Actual Age & & & 4.4 \\
$16-20$ & $90(37.7)$ & 22.60 & \\
$21-25$ & $90(37.7)$ & \\
$26-30$ & $60(25.2)$ & \\
Sex & & \\
Male & $165(68.8)$ & \\
Female & $75(31.3)$ & \\
Family Size & $15(6.3)$ & \\
$1-4$ & $159(66.3)$ & \\
5-8 & $66(27.8)$ & \\
8 and above & & \\
Educational Status & $30(12.5)$ & \\
Primary & $183(76.3)$ & \\
Secondary & $27(11.3)$ & \\
Tertiary & - & \\
No formal Education & $117(48.8)$ & \\
Religion & $114(47.5)$ & \\
Christian & $9(3.8)$ & \\
Islam & $168(70.0)$ & \\
Traditional & $72(30.0)$ & \\
Marital Status & & \\
Single & & \\
Married &
\end{tabular}

Table 2: Push factors for leaving the rural areas $(\mathrm{n}-240)$

\begin{tabular}{|c|c|c|c|c|c|}
\hline Statements & $\mathbf{S A}$ & $\mathbf{A}$ & $\mathbf{U}$ & D & SD \\
\hline & $(\%)$ & $(\%)$ & $(\%)$ & $(\%)$ & $(\%)$ \\
\hline There is poor electricity & 92.5 & 5.0 & - & 1.3 & 1.3 \\
\hline Rural roads are bad & 80.0 & 17.5 & - & 2.5 & - \\
\hline There is no pipe borne water & 75.0 & 16.3 & 5.0 & 2.5 & 1.3 \\
\hline There is no good school & 37.5 & 47.5 & 7.5 & 6.3 & 1.3 \\
\hline There is no job opportunity & 78.8 & 16.3 & 5.0 & - & - \\
\hline There is poor health care service & 43.8 & 51.2 & 3.8 & 1.3 & - \\
\hline There is under development & 78.8 & 17.5 & 3.8 & - & - \\
\hline
\end{tabular}


Table 3: Pull factors as a source of attraction to the urban areas $(\mathrm{n}-240)$

\begin{tabular}{lccccc}
\hline Statements & SA (\%) & A (\%) & U (\%) & D (\%) & SD (\%) \\
\hline Better opportunities in the city & 87.5 & 11.3 & 1.3 & - & - \\
Better wage in the city & 71.3 & 23.8 & 2.5 & 2.5 & - \\
Improved living condition & 57.5 & 30.0 & 5.0 & 5.0 & 2.5 \\
There are good schools in the city & 66.3 & 28.7 & 3.8 & 1.3 & - \\
Good electricity supply in the city & 18.8 & 71.3 & 6.3 & 3.8 & - \\
There is pipe borne water & 25.0 & 67.5 & 5.0 & 2.5 & - \\
There is better health care service & 80.0 & 16.3 & 1.3 & 1.3 & 1.3 \\
\hline
\end{tabular}

Table 4: Distribution of respondents according to their willingness to stay in rural area ( $\mathrm{n}-240)$

\begin{tabular}{ll}
\hline Willingness & $\mathrm{F}(\%)$ \\
\hline Yes & $75(31.3)$ \\
No & $\mathbf{1 6 5}(\mathbf{6 8 . 8})$ \\
\hline
\end{tabular}

The findings imply that majority of the youths migrated to the cities as result of lack of social amenities, search for better employment, to improve livelihood welfare and for the purpose of furthering education which are not available in their original place of residence but consequently found in the cities. The dichotomy between the rural and urban areas in the availability of basic amenities for the youth is responsible for rural-urban migration among the youths. This findings agree with the findings of Aromolaran (2013) who reported that the important factors responsible for youth ruralurban migration includes education needs, skills acquisition in various vocations, seeking for means of livelihood, boredom in agriculture, inadequate social amenities and expulsion due to offence and crime committed. Danejo et al. (2015) also reported that youth migrated from rural areas to urban areas due to lack of social amenities and employment in their original place of residence, for educational pursuance and to engaged themselves in one form of business or the other that generated income. Mutandwa et al. (2011) also reported that youths in Rwanda migrated for a number of reasons which include the need for temporary and permanent job opportunities, access to social services and infrastructure including roads, communication networks, as well as schooling opportunities and unfavorable social environment as shown by high poverty levels, high population density and abusive family environment. To Eze (2016), presence of impelled migration, poor income generating opportunities, escaping unfavourable conditions, transfer as a factor of migration and escaping conflict and insecurity of life were the push factors among respondents in Eastern part of Nigeria. The movement of people from the rural to urban areas is as a result of socioeconomic factors such as inferior social and economic facilities which include health care, educational opportunities, transportation system, electricity, pipe borne water, housing conditions amongst others, in the rural areas compared to those in the urban areas, and degrading view of rural areas and its inhabitants (Okhankhuele and Opafunsho, 2013).

\section{The Pull Factors as a Source of Attraction to the Urban Areas}

Results in Table 3 reveals better employment opportunities in the cities, superior wages in the urban areas, improved living condition in the cities are pull factors that attract rural youths to the urban centres. This indicates that most youths often migrate in order to improve on their living conditions. Furthermore, educational opportunities in urban areas, better supply of electricity in the urban centres, good water supply, better exposure to medical facilities were sources of attraction to the youths. The implication of this is that mass movement of youths will continue as long as the social conditions of the rural areas are not taking into consideration. People are attracted to urban areas because they think they will have greater opportunities than what is obtainable in the rural areas. Parnwell (1993) explains that a significant pull factor for rural-urban migration is based on economic reasons such as finding a job that generate more money than the individual currently earns. According to Bezemer and Headey (2008), there exists a structural warp of capital and resources that stay in the urban areas which contributes to the underdevelopment of the rural areas. Seek improved economic status, accessible destinations, join spouse, seek greater development, stay with relations, enjoy more convivial environment and engage in politics were identified by Eze (2016) as pull factor for ruralurban migration.

\section{The Perceived Effect of Youth Rural-Urban Migration}

Table 5 shows that majority of the respondents $(80 \%)$ stated that the effect of rural-urban migration on the rural area is reduction in population. This is in agreement with MohammedBello (1999) who stated that despite the subsaharan African's agrarian image, the rural peasant population is diminishing in relative size and significant. It is also in support of the work of Fapohunda (2002) which reported that mass movement of the people from the rural areas to cities brings about rural depopulation. 
Table 5: Distribution of respondents according to perceived effects of youth migration ( $\mathrm{n}-240)$

\begin{tabular}{|c|c|c|c|c|c|c|c|}
\hline Statement & $\mathrm{SA}(\%)$ & $\mathrm{A}(\%)$ & $\mathrm{U}(\%)$ & $\mathrm{D}(\%)$ & $\mathrm{SD}(\%)$ & Mean & Rank \\
\hline Child labour & 67.5 & 25.0 & 2.5 & 2.5 & $2.5 \%$ & 4.53 & $3^{\text {rd }}$ \\
\hline Reduction in agricultural production & 566.3 & 17.5 & 3.8 & 11.3 & 1.3 & 4.36 & $5^{\text {th }}$ \\
\hline Under development & 75.0 & 13.8 & 8.8 & 2.5 & - & 4.61 & $2^{\text {nd }}$ \\
\hline Loss of manpower & 55.0 & 37.5 & 6.3 & 1.3 & - & 4.46 & $4^{\text {th }}$ \\
\hline Population reduction & 80.0 & 17.5 & 1.3 & 1.3 & - & 4.76 & $1^{\text {st }}$ \\
\hline Breaking of family and cultural bond & 31.3 & 53.8 & 7.5 & 5.0 & 2.5 & 4.06 & $6^{\text {th }}$ \\
\hline
\end{tabular}

Table 6: Chi-square relationship between socioeconomic characteristics and Push Factor affecting Migration ( $\mathrm{n}-240)$

\begin{tabular}{llll}
\hline Variable & Chi-square & df & Sign \\
\hline Sex & 34.57 & 1 & 0.04 \\
Educational Level & 45.57 & 3 & 0.00 \\
Religion & 9.69 & 2 & 0.55 \\
Marital Status & 24.06 & 1 & 0.34 \\
\hline
\end{tabular}

Table 7: Pearson Correlation between age and Push Factor affecting Migration ( $\mathrm{n}$ - 240)

\begin{tabular}{lll}
\hline Variable & PPMC $(\mathbf{r})$ & Sign \\
\hline Age & 0.51 & 0.00 \\
\hline
\end{tabular}

The study further showed that $64 \%$ of respondents agreed that rural-urban migration will lead to underdevelopment of rural communities. This is because in most rural communities, community efforts are used in providing most infrastructure used among the people. In addition, the study showed that $67.5 \%$ of the respondents agreed that the persistent use of child labour in agricultural production will increase if rural-urban migration is not controlled. Also, 55\% of the respondents believe that labour force for farm work will reduce due to migration. Also, $66.3 \%$ of the respondents believed that continued reduction in agricultural production is inevitable if action is not taken to curb the rate at which the youth migrate. The effects of rural urban migration can be felt in area of the workload on the farm, decreased number of potential workers in the village, increased vulnerability (mostly for the older generation), emotional effects and economic effects for the household that in certain cases can be perceived as positive and in other cases negative.

\section{Relationship between Socio-Economic Characteristics and Push Factor Affecting Migration}

Within the developing countries, there exists a significant selectivity of migrants with respect to age, sex, caste, marital status, education, occupation and the propensity of migration differs significantly among these socio-economic groups (Hossain, 2001). The results of this study (Table 6) revealed that age $(\mathrm{r}-0.51 ; \mathrm{p}<0.01)$ of the respondents is significantly related to their decision to migrate from rural to urban areas. This implies that age influences their decision to migrate from the rural area to urban area. Based on the result of this study, majority of the respondents were young and this may account for the decision to move to the urban to look for greener pastures. The results of this study (Table 7) further revealed that sex $\left(\chi^{2}\right.$ 34.57 ; $<0.05)$ of the respondents is significantly related to their decision to migrate from rural to urban areas. This implies that sex of the respondents influences their decision to migrate from the rural area to urban area. As revealed earlier, majority of the respondents are male who are perceived to be the head and bread winners of their families, hence there is pressure on them to move to urban areas for economic empowerment to take care of their family members. As reported by Ajero et al. (2013), the major reason for this dominance of male involved in rural urban migration is because there is more pressure on the males to succeed. Therefore, the males usually migrate earlier in life and when they have stabilized, they may come back to take their family members or to marry. In addition, the results of this study revealed that educational level $\left(\chi^{2}=\right.$ 45.57; $\mathrm{p}<0.01)$ is significantly related to their migration from rural to urban areas. This implies that educational level influence their decision to move from rural to urban areas. Most of the respondents had primary and secondary education and hence may decide to move to the urban areas to further their education since no tertiary education is located in the rural communities. This is in line with Ajero et al. (2013) who opined that primary and secondary level of education represent the stage at which most people leave their parents to seek for education as some of these educational institutions may not be available in the rural areas of the migrants.

\section{CONCLUSION AND RECOMMENDATION}

Poor electricity supply, bad condition of roads and absence of pipe-borne water in rural areas were push factors driving rural youths away from their communities into urban areas. Better employment opportunities in the cities, superior wages in the urban areas, improved living condition in the cities were found to be pull factors that attract rural youths to the urban centres. The major factors that influenced rural youths' decision to migrate from rural to urban areas are age, sex and educational level. The study recommends that special incentives be offered to private firms, business outfits and companies that operate in the rural areas of the state to boost employment opportunities and 
so reduce rural migration to a minimum level. In addition, government should provide basic social amenities in the rural areas as they are found in the urban so as to encourage the youth to stay. Tax incentives should also be provided for agro-based companies to create a conducive environment for them in the rural areas of the state. This may motivate the rural youth to stay in their communities thereby contributing their quota to agricultural development.

\section{REFERENCES}

Abdur-Rokib R.A. and Abdul-Goni A. (2011). Influencing factors of socio-economic and demographic characteristics of female migrants study of Maherthaha Bangladesh. The Social Science, 6 (3), 194-197

Adewale A.O. (2005). Socio-economic factors associated with urban-rural migration in Nigeria: A case study of Oyo State. Journal of Human Ecol., 17 (1), 13-16

Ajero C.K., Madu I.A. and Mozie A.T. (2013). Appraisal of the factors of rural-urban migration in southeastern Nigeria. Innovare Jour. of Social Sciences, 1 (2), 1-8

Ango A.K., Ibrahim S.A., Yakubu A.A. and Usman T. (2014). Determination of socio-economic factors influencing youth rural-urban migration in Sokoto State, Nigeria. Nigeria Journal of Human Resource, 45 (3), 223-231

Amrevurayire E.O. and Ojeh V.N. (2016). Consequences of rural-urban migration on the source region of Ughievwen clan Delta State Nigeria. European Journal of Geography, 7 (3), $42-57$

Aromolaran A.K. (2013). Assessment of benefits associated with rural-urban migration among nonmigrant in Odeda area, Ogun State Nigeria. International Journal of Pure and Applied Sciences and Technology, 14 (2), 31-38

Aworemi J.R., Abdul-Azeez I.A. and Apoola N.A. (2011). An Appraisal of the factor influencing ruralurban migration in some selected local government areas of Lagos State, Nigeria. Journal of Sustainable Development, 4 (3), 84-86

Bezemer D. and Headey D. (2008). Agriculture, development and urban bias. World Development, 36 (8), 1342-1364

Braunvan J. (2004). Towards a renewed focus on rural development. Agric. \& Rural Dev., 11 (2), 4-6

Danejo B.U., Abubakar L.U., Haruna M.A., Usman R.A. and Bawuro B. M. (2015). Socio-economic factors influencing rural-urban migration in Wukari Local Government Area of Taraba state, Nigeria. ARPN Journal of Science and Technology, 5 (4), 201-206

Ehirim N.C., Onyeneke R.U., Chidiebera N.M., and Nnabuihe V.C. (2012). Effects and prospects of rural to urban migration on the poverty status of migrants in Abia State, Nigeria. Agricultural Science Research Journal, 2 (4), 147-149
Eze B.U. (2016). The underlying factors of rural-urban migration in southeastern Nigeria: A study in Nsukka region of Enugu state. IOSR Journal Of Humanities And Social Science, 21 (7), 46-54

Fapohunda O.J. (2002). Economics consequences of rural-urban migration in Nigeria. Imo State of Nigeria Diary, Government Printer, Owerri, Nigeria

Gilbert, Allan and Josef Gugler. 1992. Cities, Poverty \& Development, New York, Oxford University Press

Hossain M.Z. (2001). Rural-urban migration in Bangladesh: a micro level study. Paper presented at the Brazil IUSSP conference. August 20-24, 2001.

Knox P. and Marston S. (2004). Human Geography. Pearson Education. INC: New Jersey.

Mini S.E. (2000). The impact of rural-urban migration on the rural economy in Eastern Cape villages. (Unpublished paper delivered at the HSRC migration workshop, Pretoria, 17-20 March)

Mohammed-Bello Y. (1999). Not Farms Alone: A study of rural livelihoods in the middle belt of Nigeria. DARE Research. African Studies Centre. Netherlands. Pp 38-87

Mutandwa E., Kanuma-Taremwa N., Uwimana P., Gakwandi, C. and Mugisha F. (2011). An analysis of the determinants of rural to urban migraton among rural youths in northern and western provinces of Rwanda. Rwanda Journal, 22 (B), 55-95

Nwajiuba C. (2005). International Migration and livelihoods in Southeastern Nigeria. Global Migration Perspectives. Geneva No. 50.

Nwajiuba C.U. and Ejiogu A.O. (2008). Population and migration nexus. Evidence from communities of varying population densities in south east Nigeria. Oxford business and economics, Oxford, England. Proceeding of the 2008 Oxford business and economics conference held at St. Hugh's College, Oxford University, pp. 1-14

Okhankhuele O.T. and Opafunsho O.Z. (2013). Causes and consequences of rural-urban migration Nigeria: A case study of Ogun waterside local government area of Ogun state, Nigeria. British Journal of Arts and Social Sciences, 16 (I), 185-194

Parnwell M. (1993). Population movements and the Third World. London: Routledge

Pradhan K.C. (2013). Youth migration from rural to urban of western Odisha India. A micro level analysis of selective industries in Tamil Wadu, India. America Open Economic Journal, 1 (1), 1-11

Tindigarukayo J.K. (2014). The impact of rural-urban influx on Jamaican Society. International Journal of Humanities and Social Science, 4 (9), 35-40

Todaro M. (1976). Migration and economic development. A review of theory, evidence, methodology and research priorities. Mimeograph, University of Nairobi, Kenya 